Kansas and Oklahoma data also agree very well, except in the deflection of the Oklahoma maxima to the right, or two years later than Kansas, in all sections. The western portions of these States show more deviations between the curves than the central and eastern districts. Reversals of trend for these curves are indicated in 1902, 1907, $1912,1915,1916,1920$, and 1930-31.

Oklahoma and Texas, however, again indicate a tendency similar to those for the Dakotas. Eastern Oklahoma agrees fairly well with central Texas especially during early years. A reversal of trend occurs during the years 1927-31, when eastern Oklahoma data show a tendency to above normal values and Texas the reverse. Agreement is quite close between central Oklahoma and western Texas, the only serious difference occurring in early years, between 1891-1896, which probably may be due to nonhomogenous data. The western portions of these States, however, are in fair agreement, also indicating that the central and western Oklahoma data are more nearly comparable with western Texas.

As general conclusions on the matter of section similarity, the divisions in the central portion of the Plains seem to be well chosen, but adjustments are indicated in both the northern and southern extremes. As considerable labor would be involved in these redistributions, and the adjustments of only minor climatic importance, it scarcely seems advisable under present circumstances.

Considering the Great Plains, as a whole, there is remarkable uniformity in its precipitation distribution. The general tendency to a moderately skewed distribution is of course, to be expected, but the marked bimodal distribution of autumn precipitation awaits some logical explanation. Indications point toward a great frequency of very light precipitation as the cause. This frequency of precipitation in the 50-69 percent groups indicates an average daily rainfall of only 0.13 inch, based on an average precipitation for the area of 1.94 inches and 5 days of rain per month.

Several clues as to the lack of substantial precipitation are offered by Holzman (10). The theory that air masses may remove moisture from the land and only reprecipitate it under favorable conditions, and then only in insignificant amounts, may contribute largely to the lack of appreciable precipitation in the Great Plains in autumn. At this season the general movement of air masses ordinarily becomes somewhat accelerated and the Great Plains becomes invaded more frequently by the large Pc masses and thus conditions become more unfavorable for appreciable precipitation. Also, the more definite movement of the PM and PP air contribute more toward the "Chinook" effect, thus again reducing the chances for significant precipitation. It also appears that definite invasion of the region by an active air mass, probably from the Southwest or Northwest is necessary to substantial rainfall, and only in this event would the daily amounts be of sufficient magnitude to increase the seasonal totals to an entirely different class frequency.

\section{LITERATURE CITED}

(1) Atlas of American Agriculture.

(2) Thornthwaite, C. Warren. The Great Plains. In Migration and Economic Opportunity, chapter V: 202-250.

(3) Great Plains Committee. The Future of the Great Plains (1934). Report of the Great Plains Committee, December 1936.

(4) Kincer, J. B. Daytime and Nighttime Precipitation and Their Economic Significance. MonTHLY WEATHER REvIEw, 44: 628-633, 1916 .

(5) Kincer, J. B. Seasonal Distribution of Precipitation and its Frequency and Intensity in the United States. MoNTHLY WEATHER REVIEW, 47: 624-631, 1919.

(6) Jefferson, Mark. Aridity and Humidity Maps of the United States. Geographical Review 1: 203-208, 1916.

(7) Ward, Robert DeC. Climatic Subdivisions of the United States. Bulletin American Geographical Society XLVII: 672-680, 1915 .

(8) Thornthwaite, C. Warren. The Life History of Rainstorms. Geographical Review 27: 92-111, 1937.

(9) Kincer, J. B. The Climate of the Great Plains as a Factor in their Utilization. Annals Association American Geographers XIII: $67-80$.

(10) Holzman, Benjamin. Sources of Moisture for Precipitation in the United States. U. S. Department of Agriculture Technical Bulletin 589, 1937.

(11) Mills, Frederick C. Statistical Methods, New York, 1924.

\title{
A STUDY OF THE HOURLY PRECIPITATION AT OKLAHOMA CITY, OKLA.
}

By H. F. Alexander

[Weather Bureau Airport Statlon, Waynoka, Okla., October 1937]

Numerous studies of the hourly distribution of precipitation have been made during the past quarter of a century, but since all such studies are more or less local in character, it has been deemed worth while to make a similar investigation of the Oklahoma City data. Material of this kind is of value in determining rainfall insurance rates, in making local weather forecasts, in planning outdoor activities, and as a contribution to climatology.

The records for the years 1911 to 1935 , inclusive, embracing a period of 25 years, were used. The data for each month, consisting of the hourly amounts and the beginning and ending of each period of precipitation, were entered on a suitable form, after which the totals and averages were obtained. All averages used in this study are for the entire 25-year periods; in cases where there was a break in the record of hourly precipitation, as often occurred during the winter months when there was no automatic record, it was deemed permisssble to interpolate the hourly amounts.

A bibliography of easily accessible papers on similar investigations is appended.

\section{AVERAGE HOURLY AMOUNTS OF PRECIPITATION}

The average hourly amounts of precipitation for each of the 24 hours are given in Table 1 for the months and for the year. The average hourly amounts for the daytime $(7 \mathrm{a.m}$. to $7 \mathrm{p} . \mathrm{m}$.) and nighttime ( $7 \mathrm{p.m}$. to $7 \mathrm{a.m}$.) periods are given in the table also.

The data reveal the existence of a distinct diurnal period in the average hourly amounts of precipitation occurring at Oklahoma City, especially during the spring, summer, and autumn months. This characteristic begins to be apparent in March and continues throughout the summer season and into November. With the exceptions of May and July, there is a well-defined maximum period beginning just after midnight and extending until about 7 a. m.; the greatest average hourly amounts for April, June, August, and September occur between $1 \mathrm{a} . \mathrm{m}$. and $3 \mathrm{a} . \mathrm{m}$. There is also a well-defined secondary maximum in the late afternoon and early evening hours during the summer months. 
The greatest average precipitation for any hour of the year is 0.35 inch between 1 a. $m$. and 2 a. m., in June; the least, 0.02 inch between $3 \mathrm{p} . \mathrm{m}$. and $4 \mathrm{p}$. m., is also in June.

It is interesting to compare the average hourly amounts that occur during the day time with those occurring during the nighttime for a station such as Oklahoma City which may be considered to typify the conditions prevailing over a considerable area in the Great Plains region. There are no marked differences between the average amounts of daytime and nighttime precipitation at Oklahoma City during the winter season; they are practically the same for the months of November, December, and January; February, however, shows a slightly greater average for the nighttime. During the warm summer months (June, July, and August) from one and one-half to two times as much precipitation occurs during the nighttime than during the daytime. In the spring and autumn months the average amounts are almost exactly divided between daytime and nighttime. Of the 12 months, October, alone, shows a greater average hourly precipitation for the daytime.

As pointed out by Kincer ${ }^{1}$ it is a fortunate provision of nature that an excess of the total precipitation of the central Great Plains region occurs during the nighttime when it may be more economically utilized by growing plants. It is well known that evaporation takes place much more rapidly during the daytime when excessive heat and high winds dry the soil very rapidly and vitiate any benefit that might accrue from light showers. Light showers in the day time followed immediately by very high temperatures may even be distinctly harmful to tender vegetation. On the other hand, nighttime precipitation may be more economically utilized by growing plants, and the benefits are of a more lasting nature. The trend of the distribution of rainfall to the nighttime hours is doubtless of considerable value to farmers in this region, since a light seasonal precipitation, if properly distributed, may be sufficient to produce a fair crop.

There is no doubt that the diurnal variation in the amounts of precipitation is ultimately connected with the distribution of thunderstorms, which, in turn, is associated with changes in temperature and pressure. The distribution of thunderstorms is the controlling factor in determining the daily variations in precipitation during the warm months in middle latitudes. The more or less even distribution of precipitation throughout the day and night during the winter months is characteristic of a wide area in the central portion of the United States, and is due to the small number of thunderstorms experienced during that season. Most precipitation in this area during the winter months is the result of general cyclonic storms and, consequently, exhibits no distinct diurnal period.

\section{THE DURATION OF PRECIPITATION}

Comparatively little research has been done on the problem of the duration of precipitation in the United States. Therefore, it was deemed worth while to compile such data for Oklahoma City for the period 1911-35, inclusive. Note. was made of the time of beginning and ending of each period of precipitation and all intervals between showers were eliminated from the computations. In cases where the exact time of beginnings and endings was not known the times were approximated; most cases of this kind occurred at night, and were more frequent

1 J. B. Kincer, Daytime and Nighttime Precipitation and Their Economic Bignificance. MONTHL W WATHER REVIEW, 44; 630, 1916. prior to 1928 , when the inception of the airway service at Oklahoma City made it possible to check more closely the beginnings and endings of showers.

In the study of the duration of precipitation it seems desirable to disregard the intensity, and to consider hours with traces along with those having measurable amounts. Whenever the duration is computed with reference to selected hourly amounts of light intensity, serious error may result, since many hours credited with measurable amounts will simply represent the cumulative totals of previous hours.

The average annual duration of precipitation in Oklahoma City for the period 1911-35, inclusive, is 562.8 hours, or 6 percent of the total possible time. Of the total, 276.3 hours occur during the daytime (7 a. m. to 7 p. m.), and 286.5 , or slightly more than half, occur at night.

The period of greatest monthly total duration begins with the late autumn months, extends through the winter, and ends in May. January and December, with averages of 67.5 and 66.2 hours, respectively, have considerably greater total duration than any other months of the year. It is also very noticeable that the daytime and nighttime durations for the period beginning with October and ending with May are almost equal, but slightly greater for the daytime in all except March and May.

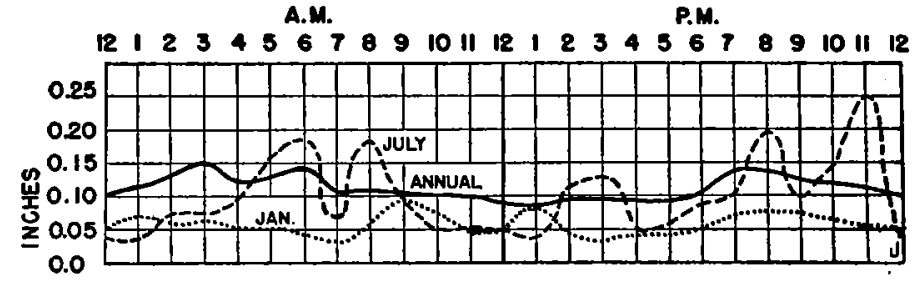
Figure 1.-A verage hourly amounts of precipitation at Oklahome City, Okla., 1911-35
inclusive.

A.M. P.M.

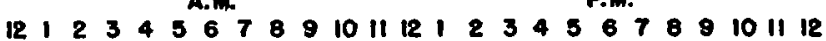

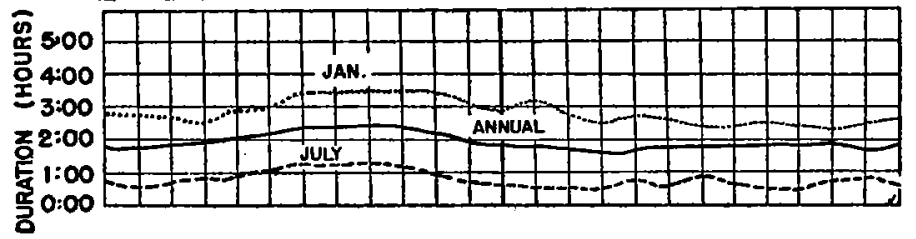
FIGURE 2.-Average hourly duration of precipitation at Oklahoma City, Okla., 1911-35

The duration of precipitation is much shorter during the summer months; it is about one-half or one-third as great as in the months of greatest duration. July, with an average of 19.9 hours, has the least total duration - of any month. It should be noted that the nighttime is greater than the daytime duration during the months of May to September, inclusive. This difference is greatest in June, when, on an average, 59 percent of the rainfall hours occurs between 7 p. m. and 7 a. $\mathrm{m}$.

Comparisons between the various months of the duration of precipitation may be more accurately made when percentages of the total possible time are used, thus eliminating discrepancies due to the unequal lengths of the months. These percentages for Oklahoma City are as follows: January, 9; February, 8; March, 8; April, 7; May, 6; June, 4; July, 3; August, 4; September, 5; October, 6; November, 8 ; and December, 9 . Taking the year as a whole, precipitation in some form is falling 6 percent of the time. 
The average duration for each hour of each month is given in table 2. Data for selected months, as well as the annual averages, are given in graphic form in figure 2. The maximum average duration, for the year as a whole, occurs in the hour ending at $8 \mathrm{a} . \mathrm{m}$., while the minimum occurs between $2 \mathrm{p} . \mathrm{m}$. and $3 \mathrm{p}$. m. There is a gradual increase in the average duration from midnight to $8 \mathrm{a.} \mathrm{m}$.; thereafter a more rapid change takes place with the duration decreasing until $3 \mathrm{p}$. $\mathrm{m}$. Probably the most outstanding feature exhibited by the data in table 2 is the persistency of the maximum in occurring between the hours of $5 \mathrm{a} . \mathrm{m}$. and $10 \mathrm{a} . \mathrm{m}$. throughout the year. In this respect the seasonal variations differ little from the annual. While there are no secondary maxima or minima of importance, there is a slight tendency for an increase in the average duration during the hours between sunset and about 11 p. m. from April to August, inclusive.

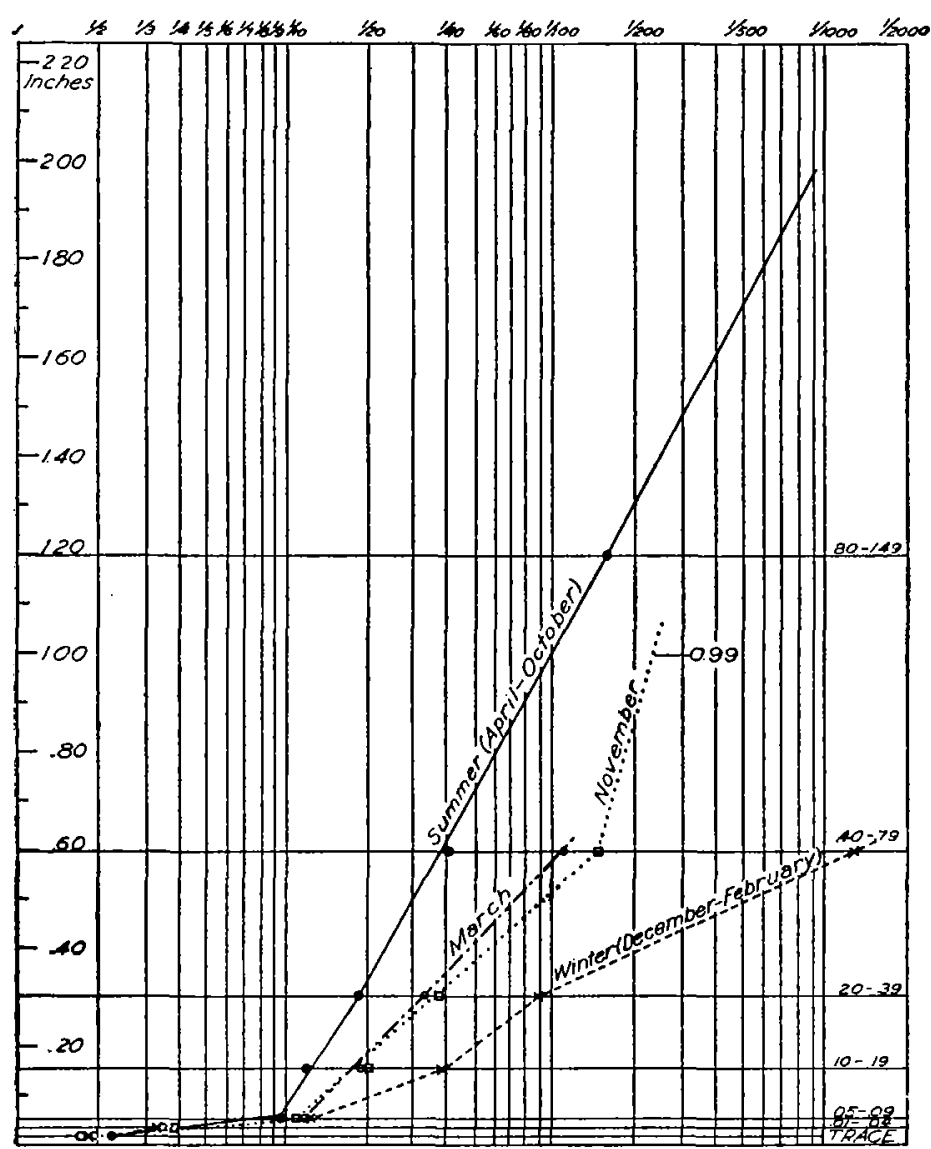

Fiaure 3.-Frequencies of intensity groups relative to total hours with precipitation at Oklahoma City, Okla., 1911-35, inclusive. Graphical representation of data pro-
sented in table 5.

The greatest hourly duration in any month occurs in January between $8 \mathrm{a}$. $\mathrm{m}$. and $9 \mathrm{a}$. $\mathrm{m}$., when it averages 3 hours and 26 minutes. Several other hours between 5 a. $m$. and 10 a. $m$. in January also have a large average duration. The least duration in any month occurs in July between midnight and $1 \mathrm{a} . \mathrm{m}$. when it averages only 30 minutes.

\section{FREQUENCY AND INTENSITY OF PRECIPITATION}

In studying the frequency of precipitation it is desirable to recognize the existence of several inherent characteristics of the data under consideration. Most important of these is the fact that the hourly entries of precipitation really represent random samples, since the 24 hours of the day are arbitrarily taken as the limits of the hourly periods. The irregular distribution of precipitation throughout the day and night results in much overlapping from one hour into the next; thus, a shower of only a few minutes duration may extend from the latter part of one into the early part of the following hour, and result in 2 hours record of precipitation. Also, a compilation of this hind involves such a large mass of data, with so many subdivisions, that special graphical methods are necessary to present the facts properly.

Table 3 shows the frequency of occurrence of hours with a trace or more, expressed as a percentage of the number of times that the particular hour occurs in the month. As would be expected, the greatest hourly frequency occurs during the period November to March, inclusive, when precipitation is recorded during about 10 percent of both the daytime and nighttime hours. The frequency distribution is fairly uniform throughout the 24-hours during the colder months of the year, but, in general, there seems to be a slightly greater frequency during the daytime.

The maximum hourly frequency occurs in the early morning hours in all months of the year; generally between 5 a. m. and 10 a. m. from September to April, inclusive, and from $6 \mathrm{a}$. $\mathrm{m}$. to $8 \mathrm{a}$. m. from May to August, inclusive.

July, with an average frequency of 4 percent of the possible hours with rain, has the least frequency of any month in the year. The hour between midnight and 1 a. $\mathrm{m}$, when 2 percent of the total hours have rain, has the least frequency of any hour during the year.

The following discussion of rainfall frequencies and intensities is based to a great extent upon the plan used by McDonald. ${ }^{2}$ It was thought desirable to use the same intensity groups and the same graphical methods for Oklahoma City, in order that the precipitation data for the two cities might be compared.

In order to provide a means of comparison between the various intensity frequencies, the hourly totals were arranged into a table of frequencies under the following headings: Trace; 0.01 to $0.04 ; 0.05$ to $0.09 ; 0.10$ to 0.19 ; 0.20 to $0.39 ; 0.40$ to $0.79 ; 0.80$ to 1.49 ; and 1.50 inches and over. It will be noticed that the groups increase in approximate geometric ratio.

In table 4 all hours with precipitation during the period 1911 to 1935 , inclusive, have been referred to their respective intensity groups. In the first column are given the total hours with precipitation during the 25 -year period together with the partial totals for daytime and nighttime Reference to this table shows that hours with only a trace are greater during the daytime $(7 \mathrm{a} . \mathrm{m}$. to $7 . \mathrm{p} \mathrm{m}$.) in all months of the year, the excess over the nighttime hours being greatest during the period December to April, inclusive. On the other hand, there seems to be a welldefined tendency for the greater rainfall intensities to occur more frequently during the nighttime during April, June, July, August, and September. During other months, however, the distribution of hours with measureable rainfall seems to be largely fortuitous.

Table 5 is based upon table 4 , and shows the relative frequency of the various groups as compared with the total rainy hours in each month. The smaller values represent the higher frequencies, since each figure indicates the average number of samples that would be necessary, as a rule, to obtain one example of the desired intensity. In other words, during the month of February, 1 hour in 3 with precipitation has had an intensity varying from 0.01 to 0.04 inch.

Although there is a wide range in the total number of hours with precipitation in the lower intensity groups,

I W. F. McDonald, Bourly Frequency and Intensity of Rainfall at New Orleans, La. MONTHLi WEATHER Review 57:1-8, Jan. 1929. 
table 5 indicates that the chance of a rainfall occurring with an intensity of 0.04 inch or less per hour is approximately the same in all months. Considerable divergence in this respect is manifest in the 0.05 to 0.09 inch group, and this tendency persists throughout the year in all the higher intensity groups.

In order to present graphically the data contained in table 5 it was thought desirable to construct figure 3 , which represents the frequency distribution of the various intensity groups. Ordinary curves are inadequate to show the relationships existing among large groups of data of this nature, so it was found necessary to plot the data on ratio-ruled paper. Any grouping of data into a straight-line relationship by this method is, as a rule, evidence of an underlying causative factor affecting the entire series. The data for the various months were arranged into groups representing the winter and summer seasons, while the intermediate months were considered separately. The winter season embraces the months of December to February, inclusive, the summer season, April to October, inclusive, while March and November, being transitional in character, were treated separately.

It is notable that the lines on the graph representing the three lowest intensity groups practically coincide for all seasons of the year. Beginning with the 0.05 to 0.09 inch group, however, there is a wide divergence in the lines representing the seasons.

The data for the summer season, especially, group themselves into a straight-line relationship, which is indicative of a single underlying causative factor (convection). The lowest intensity group totals, which, of course, have the greatest frequencies, form the first division of the graph; that is, they include those rainy hours during the summer season which are due to a combination of several causes. Starting with the fourth group, however, there is a continuous straight-line relationship that may be explained only by the fact that practically all summer-time rains of these higher intensities are due to thunderstorm activity.

The frequency distribution of various hourly amounts for the winter season does not show the close internal relationship manifested by the summer season. The hourly intensities are much lighter than during the summer, since thunderstorm activity is at a minimum. During the months of December to February, inclusive, there is a more pronounced tendency for the straight-line relationship to persist through the 0.10 to 0.19 inch group than in the summer season. This tendency is due to the fact that converging winds and the elevation of masses of air are responsible for a greater percentage of the hours with precipitation during the winter season, and, further, that these causal factors produce greater hourly intensities during the cooler portion of the year.

The months of March and November, being transitional in character, have been treated separately on the graph. Several causative factors are at work producing the precipitation that occurs during these months. It will be noted that the data for March assume a well-defined straight-line relationship, but it is thought that this result is more or less fortuitous, since convection, convergence, contact cooling, etc., are all active at that time of the year in Oklahoma City and produce a more or less haphazard precipitation pattern.

\section{BIBLIOGRAPHY}

Fassig, O. L.

Maryland Weather Service. Baltimore. 1907. Vol. 2. pp. 165-174. (Weather and climate of Baltimore.)
Cox, Henry J., and Armington, John $\mathbf{H}$.

The Weather and Climate of Chicago. University of Chicago Press. 1914.

Coberly, Edward D.

The Hourly Frequency of Precipitation at New Orleans, La. Montely Weather Review, 1914, 42: 537-538.

Fassig, O. L

Tropical Rains, Their Duration, Frequency, and Intensity. MONThl W Wather RIVIEW, 1916, 44: 329-337.

Kincer, J. B.

Daytime and Nighttime Precipitation and their Economic Significance. Monthly Whather Revirw, 1916, 44: 628-633.

Humphreys, W. J.

On the Differences Between Summer Daytime and Nighttime Precipitation in the United States. Monthly Whathen REvIEW, 1921, 49: 350-351.

Nunn, Roscoe.

Hourly Precipitation at Naghville, Tenn. Monthly Weathme REVIEW, 1922, 50: 180-184.

Tannehill, I. R.

Frequency Distribution of Daily and Hourly Amounts of Rainfall at Galveston, Texas. Monthly Weather Review, 1923, 51: 11-14.

Gorbatchev, Peter Philipovitch.

Concerning the Relation Between the Duration, Intensity, and the Periodicity of Rainfall. Monthly Whathen Review. 1923, 51: 305-309.

Sanford, Morgan R.

Hourly Precipitation at Syracuse, N. Y. Monthly Weather Ruvinw, 1923, 51: 395-396.

Carter, Harry $\mathbf{G}$.

Variations in the Hourly Rainfall at Lincoln, Nebr. Monthly WeATHER Revikw, 1924, 52: 208-211.

Flora, S. D.

Hourly Precipitation at Topeka, Kans. Monthly Weathor Review, 1924, 52: 211-212.

Feldwisch, Walter $\mathbf{F}$.

The Probabilities of $0.10 \mathrm{Inch}$, or More, of Rainfall at Springfield, Ill. Monthly Wirather Review, 1924, 52: 581-583.

French, George $M$.

Hourly Rainfall at Los Angeles, Calif. Monthly Whather Review, 1924, 52: 583 .

Loveridge, Elmer $\mathrm{H}$.

Diurnal Variation of Precipitation at Honolulu, Hawaji. Monthly Weather Review, 1924, 52: 584-585.

Ray, C. L.

Hourly Rainfall Probabilities at Lansing, Mich. Montrer WeAther REVIEW, 1925, 53: 256-258.

Shipman, Truman G.

The East Wind and its Lifting Effects at Fort Smith, Ark. Monthly Weather Revinw, 1925, 53: 536-539.

Ray, C. L.

Hourly Rainfall Probabilities at Sault Ste. Marie, Mich. Monthly Wanther Review, 1927, 55: 323-325.

Voorhees, J. F.

Distribution of Rainfall at Knoxville, Tenn., by Hours, Weeks, and Months of Four Weeks. Monthly Wentemer REvIEW, 1928, 56: 368-370.

McDonald, W. F.

Hourly Frequency and Intensity of Rainfall at New Orleans, La. Monthly Whather Rmiew, 1929, 57: 1-8.

Nunn, Roscoe.

Duration of Rainfall at Baltimore, Md. Monthly Weather ReView, 1929, 57 : 50-52.

Bennett, Walter J.

Some Characteristics of the Rainy Season at Tampa, Fla. Monthly Westher Review, 1929, 57: 323-326.

Math, Frank A.

Duration of Rainfall at Havre, Mont. Monthly Wentehr Review, 1929, 57: 468-471.

Clarke, Katharine $B$.

The Diurnal Variation of the Rainfall at Paris. Mon'thly Weather Review, 1930, 58: 333.

Armstrong, Harry.

Hourly Distribution of Rainfall at Mobile, Ala. Monthly WEATHER REVIEW, 1934, 62: 200.

Belden, W. S.

Diurnal Distribution of Rainfall at St. Joseph, Mo., April to October. Monthly Weather Review, 1936, 64: 228-230. 
TABLE 1.-Average hourly amounts of precipitation at Oklahoma City, Okla., 1911-\$5, inclusive

\begin{tabular}{|c|c|c|c|c|c|c|c|c|c|c|c|c|c|c|c|c|c|c|c|c|c|c|c|c|c|c|c|}
\hline & \multicolumn{12}{|c|}{ A. M. } & \multicolumn{12}{|c|}{ P. M. } & \multicolumn{3}{|c|}{ Hourly averages } \\
\hline & 1 & 2 & 3 & 4 & 8 & 6 & 7 & 8 & 9 & 10 & 11 & 12 & 1 & 2 & $\mathbf{3}$ & 4 & 5 & 6 & 7 & 8 & $\theta$ & 10 & 11 & 12 & $\begin{array}{l}\text { Day- } \\
\text { time }\end{array}$ & $\begin{array}{c}\text { Night- } \\
\text { time }\end{array}$ & Month \\
\hline & $\begin{array}{l}0.07 \\
.05 \\
.10 \\
.16 \\
.08 \\
.20 \\
.03 \\
.20 \\
.14 \\
.11 \\
.10 \\
.08 \\
.11\end{array}$ & $\mid \begin{array}{l}0.06 \\
.04 \\
.10 \\
.16 \\
.13 \\
.35 \\
.07 \\
.12 \\
.26 \\
.14 \\
.10 \\
.07 \\
.13\end{array}$ & $\begin{array}{l}0.06 \\
.04 \\
.17 \\
.24 \\
.16 \\
.32 \\
.07 \\
.27 \\
.12 \\
.15 \\
.13 \\
.05 \\
.15\end{array}$ & $\begin{array}{l}0.06 \\
.05 \\
.10 \\
.22 \\
.15 \\
.17 \\
.09 \\
.22 \\
.14 \\
.12 \\
.05 \\
.07 \\
.12\end{array}$ & $\begin{array}{c}0.05 \\
.04 \\
.14 \\
.20 \\
.14 \\
.21 \\
.16 \\
.17 \\
.21 \\
.14 \\
.05 \\
.07 \\
.13\end{array}$ & $\begin{array}{l}0.04 \\
.04 \\
.15 \\
.18 \\
.17 \\
.28 \\
.18 \\
.21 \\
.14 \\
.16 \\
.08 \\
.07 \\
.14\end{array}$ & $\mid \begin{array}{l}0.03 \\
.06 \\
.08 \\
.12 \\
.19 \\
.09 \\
.07 \\
.15 \\
.20 \\
.18 \\
.07 \\
.06 \\
.11\end{array}$ & $\begin{array}{l}0.06 \\
.05 \\
.07 \\
.10 \\
.21 \\
.11 \\
.18 \\
.10 \\
.14 \\
.15 \\
.08 \\
.07 \\
.11\end{array}$ & $\begin{array}{c}0.09 \\
.08 \\
.11 \\
.18 \\
.19 \\
.14 \\
.09 \\
.07 \\
.12 \\
.09 \\
.08 \\
.08 \\
.10\end{array}$ & $\begin{array}{c}0.07 \\
.05 \\
.08 \\
.10 \\
.22 \\
.08 \\
.05 \\
.07 \\
.08 \\
.16 \\
.13 \\
.08 \\
.10\end{array}$ & $\begin{array}{c}0.05 \\
.06 \\
.09 \\
.14 \\
.21 \\
.09 \\
.05 \\
.08 \\
.10 \\
.24 \\
.07 \\
.05 \\
.10\end{array}$ & $\begin{array}{l}0.05 \\
.05 \\
.07 \\
.10 \\
.17 \\
.06 \\
.05 \\
.07 \\
.08 \\
.17 \\
.07 \\
.06 \\
.08\end{array}$ & $\begin{array}{l}0.08 \\
.04 \\
.06 \\
.07 \\
.12 \\
.08 \\
.03 \\
.09 \\
.21 \\
.11 \\
.07 \\
.08\end{array}$ & $\begin{array}{l}0.04 \\
.04 \\
.04 \\
.10 \\
.14 \\
.17 \\
.11 \\
.10 \\
.08 \\
.06 \\
.08 \\
.09\end{array}$ & $\mid \begin{array}{l}0.03 \\
.04 \\
.07 \\
.10 \\
.18 \\
.06 \\
.13 \\
.07 \\
.13 \\
.12 \\
.06 \\
.07 \\
.09\end{array}$ & $\begin{array}{l}0.04 \\
.03 \\
.07 \\
.22 \\
. .14 \\
.02 \\
.05 \\
.09 \\
.09 \\
.08 \\
.07 \\
.09\end{array}$ & $\begin{array}{c}0.04 \\
.04 \\
.09 \\
.19 \\
.13 \\
.07 \\
.05 \\
.08 \\
.09 \\
.11 \\
.09 \\
.09 \\
.09\end{array}$ & $\begin{array}{l}0.05 \\
.09 \\
.07 \\
.07 \\
.12 \\
.08 \\
.10 \\
.19 \\
.10 \\
.16 \\
.12 \\
.10\end{array}$ & $\begin{array}{l}0.07 \\
.05 \\
.11 \\
.09 \\
.24 \\
.12 \\
.10 \\
.14 \\
.25 \\
.15 \\
.13 \\
.07 \\
.13\end{array}$ & $\begin{array}{l}0.07 \\
.06 \\
.14 \\
.11 \\
.28 \\
.12 \\
.19 \\
.10 \\
.14 \\
.15 \\
.14 \\
.06 \\
.13\end{array}$ & $\begin{array}{l}0.07 \\
.05 \\
.06 \\
.18 \\
. .23 \\
.10 \\
.07 \\
.14 \\
.12 \\
.09 \\
.11 \\
.12\end{array}$ & $\begin{array}{c}0.06 \\
.04 \\
.10 \\
.12 \\
.18 \\
.26 \\
.14 \\
.05 \\
.14 \\
.16 \\
.09 \\
.08 \\
.12\end{array}$ & $\begin{array}{l}0.05 \\
.06 \\
.06 \\
.10 \\
.22 \\
.15 \\
.25 \\
.05 \\
.12 \\
.16 \\
.06 \\
.07 \\
.11\end{array}$ & $\begin{array}{l}0.05 \\
.05 \\
.13 \\
.07 \\
.18 \\
.17 \\
.03 \\
.09 \\
.13 \\
.07 \\
.12 \\
.07 \\
.10\end{array}$ & $\begin{array}{r}0.06 \\
.04 \\
.08 \\
.12 \\
.17 \\
.09 \\
.08 \\
.09 \\
.12 \\
.15 \\
.09 \\
.07 \\
.10\end{array}$ & $\begin{array}{r}0.00 \\
.06 \\
.11 \\
.15 \\
.17 \\
.21 \\
.12 \\
.14 \\
.16 \\
.14 \\
.09 \\
.07 \\
.12\end{array}$ & $\begin{array}{l}1 \\
1\end{array}$ \\
\hline
\end{tabular}

Notr.- Amounts given are tor the 1-hour intervals ending at the designated clock hours. Hourly averages for the daytime and nighttime and the month are given in the columns at the right

TABLE 2.-Average hourly duration of precipitation at Oklahoma City, Okla., 1911-95, inclusive (in hours and minutes)

\begin{tabular}{|c|c|c|c|c|c|c|c|c|c|c|c|c|c|c|c|c|c|c|c|c|c|c|c|c|c|c|c|}
\hline & \multicolumn{12}{|c|}{ A. M. } & \multicolumn{12}{|c|}{ P. M. } & \multicolumn{3}{|c|}{ Totals } \\
\hline & 1 & 2 & 3 & 4 & 5 & 6 & 7 & 8 & 9 & 10 & 11 & 12 & 1 & 2 & 3 & 4 & 5 & 6 & 7 & 8 & $\theta$ & 10 & 11 & 12 & $\begin{array}{c}\text { Night- } \\
\text { time }\end{array}$ & $\begin{array}{l}\text { Day- } \\
\text { time }\end{array}$ & Month \\
\hline $\begin{array}{l}\text { July } \\
\text { August } \\
\text { Oeptember } \\
\text { October } \\
\text { November } \\
\text { December- } \\
\text { Means. }\end{array}$ & $\mid$\begin{tabular}{|l|}
$2: 44$ \\
$1: 47$ \\
$2: 25$ \\
$1: 50$ \\
$1: 28$ \\
$1: 38$ \\
$0: 30$ \\
$1: 02$ \\
$1: 35$ \\
$1: 44$ \\
$2: 19$ \\
$2: 33$ \\
$1: 48$ \\
\end{tabular} & \begin{tabular}{|l|}
$2: 37$ \\
$2: 01$ \\
$2: 22$ \\
$1: 48$ \\
$1: 52$ \\
$1: 43$ \\
$0: 45$ \\
$1: 11$ \\
$2: 06$ \\
$2: 01$ \\
$2: 12$ \\
$2: 32$ \\
$1: 55$ \\
\end{tabular} & $\begin{array}{l}2: 29 \\
1: 55 \\
2: 21 \\
1: 59 \\
2: 05 \\
2: 03 \\
0: 53 \\
1: 06 \\
2: 17 \\
2: 07 \\
2: 09 \\
2: 20 \\
1: 58\end{array}$ & $\begin{array}{l}2: 53 \\
2: 05 \\
2: 29 \\
2: 18 \\
2: 11 \\
1: 52 \\
0: 57 \\
1: 23 \\
2: 16 \\
2: 20 \\
2: 01 \\
2: 35 \\
2: 07\end{array}$ & $\begin{array}{l}3: 01 \\
2: 21 \\
2: 26 \\
2: 19 \\
2: 11 \\
2: 0 \\
1: 08 \\
1: 34 \\
2: 27 \\
2: 25 \\
2: 08 \\
2: 58 \\
2: 15\end{array}$ & $\mid \begin{array}{l}3: 20 \\
2: 46 \\
2: 33 \\
2: 22 \\
2: 03 \\
1: 40 \\
1: 11 \\
1: 50 \\
2: 12 \\
2: 17 \\
2: 12 \\
2: 57 \\
2: 17\end{array}$ & \begin{tabular}{l|}
$3: 19$ \\
$2: 59$ \\
$2: 24$ \\
$2: 13$ \\
$2: 20$ \\
$1: 48$ \\
$1: 12$ \\
$1: 58$ \\
$1: 58$ \\
$2: 35$ \\
$2: 21$ \\
$2: 56$ \\
$2: 20$
\end{tabular} & \begin{tabular}{l|}
$3: 22$ \\
$3: 08$ \\
$2: 36$ \\
$2: 22$ \\
$2: 32$ \\
$1: 48$ \\
$1: 14$ \\
$1: 41$ \\
$2: 03$ \\
$2: 46$ \\
$2: 44$ \\
$2: 52$ \\
$2: 25$
\end{tabular} & $\begin{array}{l}3: 26 \\
3: 02 \\
2: 47 \\
2: 22 \\
2: 21 \\
1: 52 \\
1: 06 \\
1: 21 \\
1: 45 \\
2: 29 \\
2: 49 \\
2: 56 \\
2: 21\end{array}$ & \begin{tabular}{|l|l|}
$3: 28$ \\
$3: 00$ \\
$2: 39$ \\
$2: 14$ \\
$2: 14$ \\
$1: 31$ \\
$0: 56$ \\
$1: 13$ \\
$1: 24$ \\
$2: 18$ \\
$2: 31$ \\
$2: 55$ \\
$2: 12$ \\
\end{tabular} & \begin{tabular}{|l|}
$3: 04$ \\
$3: 02$ \\
$2: 22$ \\
$2: 04$ \\
$1: 53$ \\
$1: 07$ \\
$0: 47$ \\
$1: 01$ \\
$1: 12$ \\
$2: 17$ \\
$2: 12$ \\
$2: 46$ \\
$1: 59$
\end{tabular} & $\mid \begin{array}{l}2: 55 \\
2: 36 \\
2: 20 \\
1: 56 \\
1: 39 \\
0: 50 \\
0: 41 \\
0: 54 \\
1: 12 \\
1: 53 \\
2: 02 \\
2: 36 \\
1: 48\end{array}$ & $\begin{array}{l}3: 07 \\
2: 22 \\
2: 11 \\
2: 03 \\
1: 35 \\
0: 55 \\
0: 35 \\
0: 52 \\
1: 10 \\
1: 46 \\
2: 14 \\
2: 41 \\
1: 84\end{array}$ & $\mid \begin{array}{l}2: 51 \\
2: 10 \\
2: 06 \\
2: 09 \\
1: 23 \\
0: 52 \\
0: 39 \\
0: 48 \\
1: 05 \\
1: 51 \\
2: 16 \\
2: 42 \\
1: 44\end{array}$ & $\mid$\begin{tabular}{l|}
$2: 29$ \\
$2: 07$ \\
$2: 10$ \\
$1: 56$ \\
$1: 22$ \\
$0: 46$ \\
$0: 37$ \\
$0: 40$ \\
$1: 22$ \\
$1: 50$ \\
$2: 06$ \\
$2: 33$ \\
$1: 40$
\end{tabular} & \begin{tabular}{|l|}
$\mathbf{2}: \mathbf{4} 0$ \\
$\mathbf{2}: 03$ \\
$\mathbf{2}: 33$ \\
$1: 52$ \\
$1: 34$ \\
$\mathbf{0}: \mathbf{4 4}$ \\
$\mathbf{0}: \mathbf{4 9}$ \\
$\mathbf{0 : 3 2}$ \\
$1: 16$ \\
$1: 51$ \\
$2: 11$ \\
$\mathbf{2}: \mathbf{4 1}$ \\
$1: \mathbf{4 4}$
\end{tabular} & $\mid$\begin{tabular}{l|}
$2: 57$ \\
$2: 04$ \\
$2: 25$ \\
$1: 43$ \\
$1: 42$ \\
$0: 47$ \\
$0: 39$ \\
$0: 48$ \\
$1: 17$ \\
$1: 52$ \\
$2: 26$ \\
$2: 59$ \\
$1: 47$
\end{tabular} & $\mid \begin{array}{l}2: 23 \\
2: 02 \\
2: 24 \\
1: 46 \\
1: 32 \\
0: 53 \\
0: 54 \\
0: 58 \\
1: 12 \\
1: 42 \\
2: 31 \\
2: 55 \\
1: 46\end{array}$ & $\begin{array}{l}2: 28 \\
2: 18 \\
2: 28 \\
1: 34 \\
1: 39 \\
0: 59 \\
0: 44 \\
1: 07 \\
1: 08 \\
1: 46 \\
2: 36 \\
2: 42 \\
1: 48\end{array}$ & $\begin{array}{l}2: 31 \\
2: 31 \\
2: 37 \\
1: 41 \\
1: 44 \\
1: 05 \\
0: 38 \\
0: 56 \\
1: 15 \\
1: 53 \\
2: 34 \\
2: 45 \\
1: 51\end{array}$ & $\mid \begin{array}{l}2: 24 \\
2: 23 \\
2: 29 \\
1: 49 \\
1: 59 \\
1: 07 \\
0: 37 \\
0: 48 \\
1: 11 \\
1: 51 \\
2: 37 \\
2: 40 \\
1: 50\end{array}$ & $\mid$\begin{tabular}{l|}
$2: 19$ \\
$2: 18$ \\
$2: 32$ \\
$1: 48$ \\
$2: 00$ \\
$1: 23$ \\
$0: 46$ \\
$1: 02$ \\
$1: 18$ \\
$1: 37$ \\
$2: 34$ \\
$2: 57$ \\
$1: 53$
\end{tabular} & $\mid$\begin{tabular}{l|}
$2: 30$ \\
$2: 14$ \\
$2: 32$ \\
$1: 34$ \\
$1: 56$ \\
$1: 25$ \\
$0: 55$ \\
$1: 03$ \\
$1: 17$ \\
$1: 36$ \\
$2: 24$ \\
$2: 56$ \\
$1: 51$ \\
1
\end{tabular} & $\begin{array}{l}2: 40 \\
2: 01 \\
2: 10 \\
1: 34 \\
1: 49 \\
1: 30 \\
0: 39 \\
0: 55 \\
1: 29 \\
1: 40 \\
2: 30 \\
2: 44 \\
1: 48\end{array}$ & $\begin{array}{l}32: 47 \\
27: 21 \\
29: 11 \\
23: 15 \\
23: 38 \\
19: 06 \\
10: 11 \\
11: 48 \\
21: 19 \\
24: 06 \\
27: 58 \\
32: 53 \\
23: 53\end{array}$ & $\begin{array}{l}34: 43 \\
29: 52 \\
29: 01 \\
24: 11 \\
21: 12 \\
13: 04 \\
9: 41 \\
11: 55 \\
18: 06 \\
24: 21 \\
28: 38 \\
33: 18 \\
23: 02\end{array}$ & $\begin{array}{l}67: 30 \\
57: 13 \\
58: 12 \\
47: 28 \\
45: 04 \\
32: 10 \\
19: 52 \\
28: 43 \\
37: 25 \\
48: 27 \\
56: 36 \\
66: 11 \\
46: 55\end{array}$ \\
\hline
\end{tabular}

Norr. - Entires represent the average duratjon per month of precipitation during each hour of the day. Totals for the daytime and nighttime periods, and for the month, are given in the columns at the right.

TABLE 3.-Average hourly frequencies of precipitation, expressed as a percentage of the total possible hours in the month, at Oklahoma City, Okla., 1911-85, inclusive

\begin{tabular}{|c|c|c|c|c|c|c|c|c|c|c|c|c|c|c|c|c|c|c|c|c|c|c|c|c|c|c|c|}
\hline & \multicolumn{12}{|c|}{ A. M. } & \multicolumn{12}{|c|}{ P. M. } & \multicolumn{3}{|c|}{ A verages } \\
\hline & 1 & 2 & $\mathbf{3}$ & 4 & 5 & 6 & 7 & 8 & 9 & 10 & 11 & 12 & 1 & 2 & 3 & 4 & 5 & 6 & 7 & 8 & 9 & 10 & 11 & 12 & $\begin{array}{l}\text { Day- } \\
\text { time }\end{array}$ & $\begin{array}{c}\text { Night- } \\
\text { time }\end{array}$ & Month- \\
\hline $\begin{array}{l}\text { November } \\
\text { December }\end{array}$ & $\begin{array}{r}10 \\
7 \\
9 \\
7 \\
6 \\
6 \\
2 \\
4 \\
7 \\
7 \\
6 \\
9 \\
9\end{array}$ & $\begin{array}{r}9 \\
9 \\
9 \\
8 \\
7 \\
8 \\
3 \\
5 \\
8 \\
7 \\
8 \\
8 \\
10\end{array}$ & $\begin{array}{r}10 \\
8 \\
10 \\
8 \\
8 \\
8 \\
4 \\
5 \\
9 \\
8 \\
8 \\
9 \\
10\end{array}$ & $\begin{array}{r}\mathbf{1 1} \\
\mathbf{9} \\
\mathbf{9} \\
\mathbf{9} \\
\mathbf{8} \\
\mathbf{9} \\
\mathbf{5} \\
\mathbf{6} \\
\mathbf{9} \\
\mathbf{9} \\
\mathbf{8} \\
\mathbf{1 0}\end{array}$ & $\begin{array}{r}12 \\
11 \\
9 \\
11 \\
9 \\
9 \\
5 \\
7 \\
10 \\
10 \\
9 \\
11\end{array}$ & $\begin{array}{r}13 \\
11 \\
10 \\
11 \\
10 \\
9 \\
6 \\
9 \\
10 \\
9 \\
9 \\
11\end{array}$ & $\begin{array}{l}12 \\
12 \\
10 \\
12 \\
11 \\
10 \\
7 \\
10 \\
10 \\
11 \\
10 \\
11\end{array}$ & $\begin{array}{l}13 \\
14 \\
11 \\
10 \\
13 \\
11 \\
7 \\
10 \\
11 \\
12 \\
11 \\
12\end{array}$ & $\begin{array}{r}13 \\
13 \\
11 \\
11 \\
11 \\
9 \\
6 \\
7 \\
9 \\
11 \\
11 \\
11\end{array}$ & $\begin{array}{r}13 \\
13 \\
11 \\
12 \\
10 \\
8 \\
5 \\
6 \\
8 \\
10 \\
10 \\
11\end{array}$ & $\begin{array}{r}11 \\
12 \\
10 \\
10 \\
9 \\
7 \\
4 \\
5 \\
6 \\
10 \\
9 \\
11\end{array}$ & $\begin{array}{r}12 \\
12 \\
10 \\
10 \\
8 \\
5 \\
3 \\
5 \\
6 \\
8 \\
8 \\
10\end{array}$ & $\begin{array}{r}12 \\
10 \\
9 \\
10 \\
7 \\
6 \\
3 \\
6 \\
6 \\
8 \\
9 \\
10\end{array}$ & $\begin{array}{r}11 \\
\mathbf{g} \\
\mathbf{g} \\
\mathbf{9} \\
7 \\
5 \\
4 \\
5 \\
6 \\
8 \\
9 \\
10\end{array}$ & $\begin{array}{r}10 \\
9 \\
10 \\
9 \\
7 \\
5 \\
4 \\
4 \\
7 \\
7 \\
8 \\
9 \\
10\end{array}$ & $\begin{array}{r}10 \\
10 \\
10 \\
9 \\
8 \\
5 \\
5 \\
4 \\
6 \\
8 \\
9 \\
10\end{array}$ & $\begin{array}{r}10 \\
9 \\
10 \\
8 \\
9 \\
5 \\
4 \\
5 \\
6 \\
8 \\
10 \\
11\end{array}$ & $\begin{array}{r}9 \\
8 \\
10 \\
9 \\
7 \\
6 \\
5 \\
8 \\
6 \\
8 \\
10 \\
11\end{array}$ & $\begin{array}{r}10 \\
9 \\
10 \\
8 \\
8 \\
6 \\
4 \\
6 \\
6 \\
8 \\
10 \\
10\end{array}$ & $\begin{array}{r}10 \\
10 \\
11 \\
8 \\
9 \\
6 \\
3 \\
5 \\
6 \\
8 \\
10 \\
10\end{array}$ & $\begin{array}{r}9 \\
10 \\
10 \\
9 \\
\mathbf{9} \\
\mathbf{5} \\
\mathbf{3} \\
\mathbf{3} \\
\mathbf{6} \\
7 \\
10 \\
10\end{array}$ & $\begin{array}{r}9 \\
9 \\
9 \\
8 \\
9 \\
7 \\
4 \\
5 \\
6 \\
7 \\
10 \\
11\end{array}$ & $\begin{array}{r}9 \\
9 \\
10 \\
7 \\
8 \\
6 \\
4 \\
5 \\
6 \\
8 \\
9 \\
11\end{array}$ & $\begin{array}{r}10 \\
8 \\
8 \\
7 \\
8 \\
6 \\
3 \\
5 \\
5 \\
6 \\
10 \\
10\end{array}$ & $\begin{array}{r}11 \\
\mathbf{1 1} \\
10 \\
10 \\
\mathbf{9} \\
7 \\
5 \\
\mathbf{6} \\
7 \\
\mathbf{9} \\
10 \\
11\end{array}$ & $\begin{array}{r}10 \\
10 \\
9 \\
9 \\
9 \\
9 \\
7 \\
4 \\
6 \\
8 \\
8 \\
9 \\
10\end{array}$ & $\begin{array}{l}11 \\
10 \\
10\end{array}$ \\
\hline
\end{tabular}

TABLE 4.-Frequency of selected hourly rainfall intensities at Oklahoma City, Okla., 1911-35, inclusive

\begin{tabular}{|c|c|c|c|c|c|c|c|c|c|}
\hline \multirow[b]{2}{*}{ Month } & \multirow{2}{*}{$\begin{array}{c}\text { Total hours } \\
\text { with pre- } \\
\text { cipitation } \\
\text { of any } \\
\text { amount }\end{array}$} & \multirow[b]{2}{*}{ Trace } & \multicolumn{7}{|c|}{ Intensity group totals } \\
\hline & & & $\begin{array}{c}0.01 \\
\text { to } \\
0.04\end{array}$ & $\begin{array}{c}0.05 \\
\text { to } \\
0.09\end{array}$ & $\begin{array}{c}0.10 \\
\text { to } \\
0.19\end{array}$ & $\begin{array}{c}0.20 \\
\text { to } \\
0.39\end{array}$ & $\begin{array}{c}0.40 \\
\text { to } \\
0.79\end{array}$ & $\begin{array}{l}0.80 \\
\text { to } \\
1.49\end{array}$ & $\begin{array}{l}1.50 \\
\text { and } \\
\text { over }\end{array}$ \\
\hline January _. & (a) 1,029 & $\begin{array}{l}659 \\
533\end{array}$ & $\begin{array}{l}268 \\
310\end{array}$ & $\begin{array}{l}65 \\
66\end{array}$ & $\begin{array}{l}23 \\
33\end{array}$ & $\begin{array}{l}10 \\
13\end{array}$ & 3 & & \\
\hline & (c) 1,983 & 1, 192 & 578 & $\begin{array}{r}60 \\
131\end{array}$ & 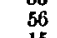 & 23 & 3 & & \\
\hline February & $\begin{array}{l}\text { (a) } 908 \\
\text { (b) } 811\end{array}$ & $\begin{array}{r}553 \\
421\end{array}$ & $\begin{array}{l}271 \\
300\end{array}$ & $\begin{array}{l}65 \\
65\end{array}$ & $\begin{array}{l}15 \\
14\end{array}$ & $\begin{array}{r}4 \\
10\end{array}$ & 1 & -- & (n) \\
\hline March. & $\begin{array}{l}\text { (c) } 1719 \\
\text { (a) } 234\end{array}$ & $\begin{array}{l}974 \\
615\end{array}$ & $\begin{array}{l}571 \\
267\end{array}$ & $\begin{array}{r}130 \\
86\end{array}$ & $\begin{array}{l}29 \\
47\end{array}$ & $\begin{array}{l}14 \\
15\end{array}$ & $\begin{array}{l}1 \\
4\end{array}$ & -...- & \\
\hline & (b) 875 & $\begin{array}{l}453 \\
968\end{array}$ & $\begin{array}{l}269 \\
536\end{array}$ & $\begin{array}{r}55 \\
141\end{array}$ & 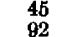 & . 40 & $\begin{array}{l}13 \\
17\end{array}$ & -..- & \\
\hline April_. & (a) 880 & 422 & 249 & 84 & 60 & 28 & 15 & 2 & $\cdots$ \\
\hline & (c) 1,634 & 739 & 470 & 173 & 135 & 80 & 32 & 5 & \\
\hline May & (a) 818 & 381 & 197 & 83 & 68 & 50 & 20 & $\begin{array}{l}9 \\
0\end{array}$ & \\
\hline & (c) 1.626 & 748 & 428 & 169 & 124 & 要9 & 42 & & 1 \\
\hline June... & $\begin{array}{l}\text { (a) } 587 \\
\text { (b) } 670\end{array}$ & $\begin{array}{l}293 \\
238\end{array}$ & $\begin{array}{l}157 \\
109\end{array}$ & $\begin{array}{l}57 \\
77\end{array}$ & $\begin{array}{l}45 \\
74\end{array}$ & 21 & $\begin{array}{r}\mathbf{9} \\
\mathbf{2 3}\end{array}$ & $\begin{array}{l}5 \\
8\end{array}$ & 5 \\
\hline July___ & $\begin{array}{l}\text { (c) } 1,257 \\
\text { (a) } 424\end{array}$ & $\begin{array}{l}531 \\
209\end{array}$ & $\begin{array}{l}356 \\
105\end{array}$ & $\begin{array}{r}134 \\
45\end{array}$ & $\begin{array}{r}119 \\
30\end{array}$ & $\begin{array}{l}67 \\
18\end{array}$ & $\begin{array}{l}32 \\
16\end{array}$ & $\begin{array}{r}\mathbf{1 3} \\
\mathbf{3}\end{array}$ & 5 \\
\hline & & 357 & 229 & 75 & 要3 & 33 & 27 & & 3 \\
\hline August_.. & (a) 528 & 247 & 148 & 59 & 38 & 21 & 13 & 1 & 1 \\
\hline & (c) 1,069 & 437 & 299 & 134 & 97 & 56 & 28 & 6 & \\
\hline Beptember. & $\begin{array}{l}\text { (a) } 624 \\
\text { (b) } 684\end{array}$ & 253 & 230 & $\begin{array}{l}55 \\
76\end{array}$ & 48 & 46 & $\begin{array}{l}13 \\
26\end{array}$ & $\begin{array}{l}2 \\
5\end{array}$ & 2 \\
\hline October... & (c) 1, & $\begin{array}{l}549 \\
335\end{array}$ & $\begin{array}{l}411 \\
265\end{array}$ & $\begin{array}{r}131 \\
98\end{array}$ & $\begin{array}{l}89 \\
83\end{array}$ & $\begin{array}{l}80 \\
22\end{array}$ & $\begin{array}{l}39 \\
17\end{array}$ & $\begin{array}{l}7 \\
4\end{array}$ & $\begin{array}{l}2 \\
2\end{array}$ \\
\hline & (c) 734 & 271 & 259 & $\begin{array}{r}75 \\
173\end{array}$ & $\begin{array}{r}65 \\
148\end{array}$ & $\begin{array}{l}48 \\
70\end{array}-x-10$ & 13 & $\begin{array}{l}3 \\
7\end{array}$ & $-\overline{2}$ \\
\hline Novem & $\begin{array}{r}\text { (()) } 881 \\
\text { (b) } 829 \\
\text { (c) } 1,710\end{array}$ & $\begin{array}{l}525 \\
461 \\
986\end{array}$ & $\begin{array}{l}202 \\
238 \\
440\end{array}$ & $\begin{array}{r}70 \\
67 \\
137\end{array}$ & $\begin{array}{l}58 \\
27 \\
85\end{array}$ & $\begin{array}{l}18 \\
26 \\
44\end{array}$ & $\begin{array}{r}\mathbf{4} \\
7 \\
11\end{array}$ & $\begin{array}{l}4 \\
3 \\
7\end{array}$ & $\mid--$. \\
\hline
\end{tabular}

TA BLE 4.-Frequency of selected hourly rainfall intensities at Oklahoma City, Okla., 1911-35, inclusive-Continued

\begin{tabular}{|c|c|c|c|c|c|c|c|c|c|}
\hline \multirow[b]{2}{*}{ Month } & \multirow{2}{*}{$\begin{array}{l}\text { Total hours } \\
\text { with pre- } \\
\text { cipitation } \\
\text { of any } \\
\text { amount }\end{array}$} & \multirow[b]{2}{*}{ Trace } & \multicolumn{7}{|c|}{ Intensity group totals } \\
\hline & & & $\begin{array}{c}0.01 \\
\text { to } \\
0.04\end{array}$ & $\begin{array}{c}0.05 \\
\text { to } \\
0.00\end{array}$ & $\begin{array}{c}0.10 \\
\text { to } \\
0.19\end{array}$ & $\begin{array}{c}0.20 \\
\text { to } \\
0.38\end{array}$ & $\begin{array}{c}0.40 \\
\text { to } \\
0.79\end{array}$ & $\begin{array}{c}0.80 \\
\text { to } \\
1.48\end{array}$ & $\begin{array}{l}1.50 \\
\text { and } \\
\text { over }\end{array}$ \\
\hline December.. & $\begin{array}{r}\text { (a) } 983 \\
\text { (b) } 959 \\
\text { (c) } 1,942\end{array}$ & $\begin{array}{r}589 \\
509 \\
1,093\end{array}$ & $\begin{array}{l}246 \\
297 \\
543\end{array}$ & $\begin{array}{r}77 \\
100 \\
177\end{array}$ & $\begin{array}{l}51 \\
39 \\
90\end{array}$ & $\begin{array}{l}19 \\
14 \\
33\end{array}$ & $\begin{array}{c}1 \\
1\end{array}$ & & $\cdots$ \\
\hline
\end{tabular}

(a) Daytime totals for period of record (1911-36).

(b) Totals for entire period of record.

TABLE 5.-Frequencies of intensity groups relative to total houra with precipitation, Oklahoma City, Okla., 1911-35, inclusive

\begin{tabular}{|c|c|c|c|c|c|c|c|c|}
\hline & Trace & $\begin{array}{c}0.01 \\
\text { to } \\
0.04\end{array}$ & $\begin{array}{c}0.05 \\
\text { to } \\
0.09\end{array}$ & $\begin{array}{c}0.10 \\
\text { to } \\
0.19\end{array}$ & $\begin{array}{c}0.20 \\
\text { to } \\
0.39\end{array}$ & $\begin{array}{c}0.40 \\
\text { to } \\
0.79\end{array}$ & $\begin{array}{c}0.80 \\
\text { to } \\
1.49\end{array}$ & $\begin{array}{l}1.60 \\
\text { and } \\
\text { over }\end{array}$ \\
\hline January & 1.7 & 3.4 & $\begin{array}{l}15.1 \\
13.2\end{array}$ & $\begin{array}{r}35.4 \\
59.3\end{array}$ & 86. 2 & $\begin{array}{r}661.0 \\
1.719 .0\end{array}$ & & \\
\hline Marc & 1.8 & $\begin{array}{l}3.4 \\
3.4\end{array}$ & 12.8 & 19.7 & 32.9 & 106.4 & & \\
\hline & & 3. 5 & 8.4 & 12.1 & 20.4 & 51.1 & 320.8 & \\
\hline ay -. & & 3.8 & 9.6 & 13.1 & 16. 4 & 38.7 & 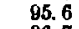 & 1,0260 \\
\hline & 0.7 & 3.5 & 9.4 & 10.8 & 18.8 & 39.3 & 96.7 & 261.4 \\
\hline July & 2.2 & 3.5 & 10.7 & 12.7 & 24. 2 & 29.6 & 66.6 & 26 \\
\hline Augus & 2.4 & 3.5 & 7.9 & 10. 9 & 18. 9 & 37.8 & 176. 5 & 52 \\
\hline Septen & 2.4 & 3.2 & 10.0 & 14.7 & 16.4 & 33.5 & 186.9 & 664.0 \\
\hline Octol & 2.8 & 3.0 & 9.0 & 10.5 & 22.3 & 52.0 & 222.8 & 780.0 \\
\hline $\begin{array}{l}\text { November- } \\
\text { December- }\end{array}$ & $\begin{array}{l}1.7 \\
1.8\end{array}$ & $\begin{array}{l}3.9 \\
3.6\end{array}$ & $\begin{array}{l}12.5 \\
11.0\end{array}$ & 21.6 & $\begin{array}{l}38.8 \\
58.8\end{array}$ & $\left|\begin{array}{r}155.4 \\
1,942.0\end{array}\right|$ & 244. 3 & \\
\hline Group aver & & & & & & & & \\
\hline Winter (1) & $\begin{array}{l}1.8 \\
2.3\end{array}$ & $\begin{array}{l}3.3 \\
3.4\end{array}$ & 13. 1 & $\begin{array}{l}38.8 \\
121\end{array}$ & 89.3 & {$[1,40.7$} & 107.4 & 586.7 \\
\hline Summer & & & & & & & & sot. \\
\hline
\end{tabular}

